УДК 1751

\title{
ИСТОРИЯ ФУНКЦИОНИРОВАНИЯ ТАТАРСКОГО ЯЗЫКА В СИСТЕМЕ НАЦИОНАЛЬНОГО ОБРАЗОВАНИЯ
}

\author{
Шамсутдинова Расима Равиловна \\ канд.филол.наук, доцент \\ Гилязова Лилия Гильмутдиновна \\ канд.филол.наук \\ Фаттахова Рузиля Фердависовна \\ канд.филол.наук, доцент \\ ГАОУ ДПО “Институт развития \\ образования Республики Татарстан”
}

Аннотация: В статье освещается история функционирования татарского языка в сфере образования во второй половине 19 века, образования научных терминов на татарском языке и роль татарских просветителей в процессе сближения письменного литературного языка с общенародным разговорным языком.

Ключевые слова: Терминология на татарском языке, светское образование, проблема обучения на родном языке, передовые татарские педагоги, терминология на татарском языке.

\section{HISTORY OF THE FUNCTIONING OF THE TATAR LANGUAGE IN THE SYSTEM OF NATIONAL EDUCATION}

\author{
Shamsutdinova Rasima Ravilovna \\ Gilyazova Lilia Gilmutdinovna \\ Fattakhova Rusilja Ferdavisovna
}

\begin{abstract}
The article covers the history of the functioning of the Tatar language in the field of education in the second half of the 19th century, the formation of scientific terms in the Tatar language and the role of Tatar educators in the process of rapprochement of the written literary language with the national spoken language.
\end{abstract}




\section{ВСЕРОССИЙСКИЙ ФИЛОЛОГИЧЕСКИЙ ФОРУМ}

Key words: Terminology in the Tatar language, secular education, the problem of teaching in the native language, advanced Tatar teachers, terminology in the Tatar language.

Учебная литература общего содержания для татарских школ развивается во второй половине 19 века и их особенностью является то, что преобладающее большинство их написано на татарском языке с использованием терминологии на татарском языке.

Увеличение количества и наименований учебных пособий и учебников общего содержания для татарской школы было обусловлено распространением светского образования среди татар, энергичной деятельностью передовых татарских педагогов, наличием опыта составления учебной литературы , учебных планов, программ для школ. Издавались серии учебников, состоящие из нескольких книг. Одним из первых печатает серию из 4 учебников по географии К. Насыйри, куда вошли книги по географической терминологии, по географии Африки, Азии, Аравийского полуострова. Им был написан учебник по географии России и составлен школьный атлас, которые остались неопубликованными. Серию учебников издают так же Х. Файзи, М. Курбангалиев, Г. Фаизханов и др. Издание учебников сериями является большим достижением татарских педагогов, ибо они содействуют достижению единства и преемственности во всем курсе, исключают дублирование.

Передовые татарские педагоги заостряли внимание общественности на необходимости обучения и просвещения на родном языке. Как и передовые татарские педагоги, авторы учебников К.Насыйри, Г. Фаизханов, Ш.Габдельгазизов, М. Курбангалиев, З.Шакиров, Г. Фахретдинов и др. считали родной язык основой школьного обучения, средством просвещения народа.

Создание и развитие учебной литературы общего содержания свидетельствует о борьбе прогрессивной татарской общественности за внедрение светского образования в школы, эти учебники были направлены на повышение интереса к изучаемому предмету, на развитие мышления. Они пользовались успехом и широко применялись в татарских школах. Особенно восторженно были приняты первые учебники с общим содержанием. Большой вклад в защиту татарского языка, в первоначальную его разработку внес К.Насыйри. Татарская интеллигенция во главе с великим просветителем 
выступили в защиту идеи сближения письменного литературного языка с общенародным разговорным языком. Это было особенно важным в связи с тем, что в старотатарском языке было огромное количество арабских, персидских, турецких заимствований. Положительные отзывы об учебниках К.Насыйри дали М.Гафури, профессор В. Смирнов и др. В. Смирнов писал: «Можно считать отрадным явлением издание учебников географии, грамматики» (13, Классик татарской литературы Мажит Гафури, высоко оценивая научное содержание этих учебников и факт их издания на татарском языке, писал: “География на татарском языке! Татарская грамматика! Геометрия на татарском языке! Арифметика на татарском языке! А на обложке этих книг написано: составитель Абдул-Каюм Абдул-Насыров. Для людей, которым уже надоело все то, чему учили в старом медресе, эти книги доставляли духовную пищу, читая их, нам хотелось стать на новый путь” [8, c.107.].

Для татарской школы проблема обучения на родном языке в то время представляла большую сложность. С одной стороны, давление русского царизма по отношению к культуре нерусских народов, с другой - отход от национальных традиций, родного языка и быта, чрезмерное увлечение арабским, персидским и турецкими языками - порождали опасность вырождения нации. Передовые татарские педагоги являлись убежденными сторонниками обучения на родном языке, они показывали изъяны воспитания татар на не родном для них языке.

Учебники, составленные татарскими педагогами, использовались не только в татарских школах, но и в школах других тюркоязычных народов башкир, казахов и др. Просветитель татарского и башкирского народа М.Гафури писал: «Наверное, нет человека среди татар и башкир внутренней России, кто за последние 10-15 лет не учился бы по учебникам Мухутдина Курбангалеева, кто бы не испытал большой пользы от его трудов. Этот большой педагог известен своими учебниками многочисленным ученикам, живущим за тысячи километров от Казани, а татарским и башкирским учителям своими произведениями по языку, орфографии и методам обучения. С этой точки зрения его заслуги неизмеримы и плоды помощи татарским и башкирским школам неисчислимы» [8]. Распространение учебников татарских педагогов среди других народов отмечают и официальные органы. В журнале особого совещания было записано: «... учебники казанского издания имеют распространение далеко за пределами Казанской губернии, 
что делает казанских татар духовными руководителями значительной части российского мусульманства» [12,с. 326].

Благодаря учебникам светское образование все решительнее пробивало себе дорогу и выдвигалось на передний план. Осознавая все возрастающую роль в жизни общества науки вообще, педагогической в частности, учителяметодисты стремились оказать помощь нации в ее прогрессивном движении вперед.

Мухутдин Курбангалеев - видный татарский педагог и ученый - был сторонником и последователем К.Насыйри в борьбе за внедрение татарского языка. Он вспоминал: «Всегда, на каждом собрании по вопросам языка и орфографии я был сторонником К. Насыйри. В течении 30-летней педагогической и литературной деятельности я старался осуществить практические принципы К. Насыйри. Таких, которые, как и я, шли по его пути, было много”[5 ]. Ведя борьбу за обучение детей в школах на родном языке, татарские педагоги, ученые провели большую работу по формированию татарского научного языка, обогатили татарский язык необходимым минимумом научных терминов. При этом они боролись за чистоту родного языка, за доступность образования широким массам. Источником специальной терминологии старотатарского языка служили заимствования из арабского, персидского и турецкого языков, а природный татарский язык, считался уделом села и быта, языком простонародия. Авторы учебников пытаются отказаться от этих заимствований, поскольку соответствующие термины имеются в татарском языке. Они защищают право татарского народа на самостоятельное развитие и выдвигают требование создания специальных терминов на основе народно-разговорной речи. Так, например, для первых учебных пособий по географии [1; 4;], хотя еще и характерно преобладание арабских терминов (напр.: харита-карта, жсәзирә остров, шимал - север, гареб - запад и др.), но уже наблюдается использование терминов на татарском языке, напр.: елпак тау - плоскогорье, елга - река, күл - озеро, сазльк - болто, елга башы- исток, елга тамагы устье и др. Г. Фаизханов впервые вводит следующие термины: дала - степь, чүл - пустыня, култык - залив, яссы таулькк - возвышенность, атау - остров, ярым атав - полуостров, тоташ тавлар - горные цепи, утльл тав - вулкан и др.[11]

К. Насыйри в своих учебниках по геогрфии продолжает работу над введением терминов, созданных на тюркской основе. Он пользуется такими 
терминами, как коры ж⿻ир - суша, муен - перешеек, кинулек - широта, озынльлк - долгота, елга - река, диңгез - море, утлаук - перевал, шәрләмә - водопад, түбанлек - низменность, жсир тетрәү - землетрясение.

Ш. Габдельгазизов, продолжая работу над терминологией, использует следующие термины: атау - остров, ярым атау - полуостров, тау - гора, уm тау - вулкан, борын - мысь, тамак - устье, күл-озеро, чишмә - родник, кояш тотлывы - солнечное затмение, кара туфрак - чернозем и др. [2]. Продолжая работу над формированием татарских терминов, авторы этих учебников доказали жизненность татарского научного языка и работая над созданием терминов, одновременно искали пути их внедрения, добивались, чтобы их приняли учителя и учащиеся.

\section{Список литературы}

1. Фонд 1, опись3, дело 9073, 32лл.

2. Распоряжение «О том, чтобы в магометанских школах были употребляемы не рукописные, а печатные книги, и к преподаванию допускались лишь русские подданные, получившие образование в России». //Циркуляр Казан. учеб. округу, 1892, №7. - С. 389.

3. Фонд 821 , оп.8, д.834.

4. Фонд 777 , оп.4, д.3

5. Фонд 776, оп. 20, д.1062

6. Фонд 969, оп. 1, д.20.

7. Ашмарин Н.И. Несколько слов о современной литературе казанских татар. - СПб.:Сенатская тип., 1905. - 31с.

8. Гафури М. Тормыш юлым. Истәлекләр. - Казан: Таткнигоиздат, 1952. -127 б.

9. Каримуллин А.Г. Татарская книга пореформенной России. - Казань: Таткнигоиздат, 1983. - 320 с.

10. Коблов Я.Д. Конфес. школы казанских татар. - Казань, 1916. - 119с.

11. Кудаш с. По следам юности. - М.: Сов. писатель, 1968. -247 с.

12. Нафигов Р.И. Формирование и развитие передовой татарской общественно-политической мысли. - Казань: изд-во КГУ, 1964,- 446 с.

13. Смирнов В.О. Мусульманские печатные издания в России//Записки восточного отделения Русского археологического общества, 1888. -т.3- 4, 97 с.

14. Файзи Х. Тагълим жәгърафия. -Казань: тип. Харитонова, 1915.98 с. 